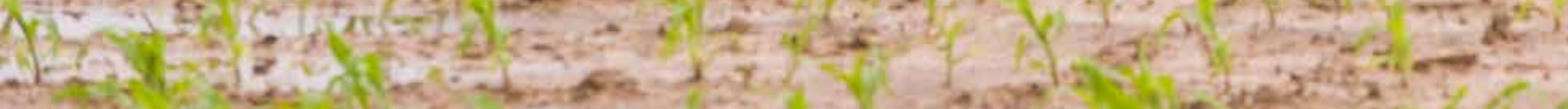

$x \rightarrow 0 x$ inde?

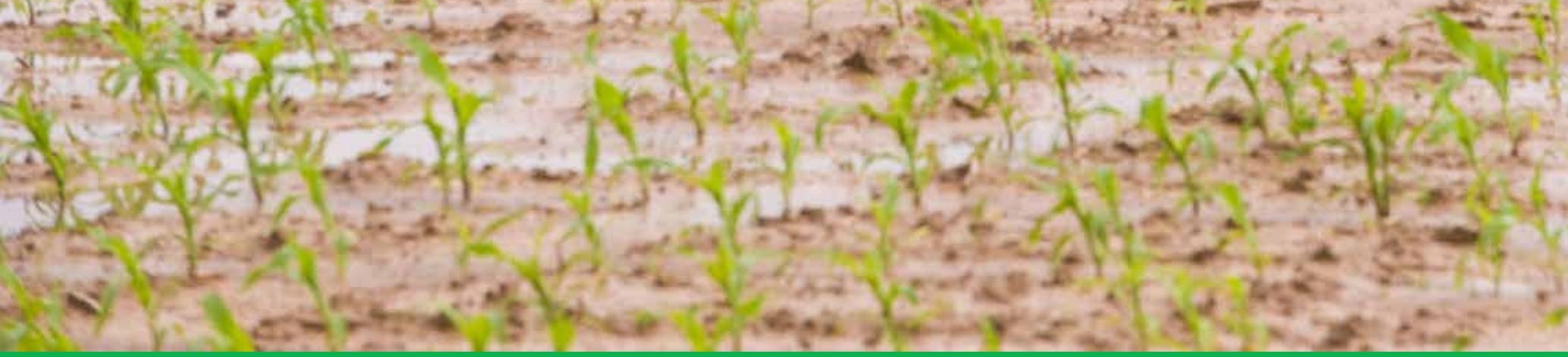

\title{
Het effect van een herziening \\ Regeling Brede Weersverzekering op de subsidieomvang
}

Marcel van Asseldonk 



\section{Het effect van een herziening Regeling Brede Weersverzekering op de subsidieomvang}

Marcel van Asseldonk

Dit onderzoek is uitgevoerd door Wageningen Economic Research in opdracht van en gefinancierd door het ministerie van Landbouw, Natuur en Voedselkwaliteit, in het kader van het Beleidsondersteunend onderzoeksthema 'Agri-Food' (projectnummer BO-43-014.01-021).

Wageningen Economic Research

Wageningen, november 2018

NOTA

2018-096 
Van Asseldonk, M., 2018. Het effect van een herziening Regeling Brede Weersverzekering op de subsidieomvang. Wageningen, Wageningen Economic Research, Nota 2018-096. 18 blz.; 4 fig.; 2 tab.; 8 ref.

Sinds openstelling van de Regeling Brede Weersverzekering in 2010 is het aantal verzekerde telers toegenomen tot 1.812 in 2018. De Europese Raad van landbouwministers heeft eind december 2017 ingestemd met de landbouwonderdelen van de Omnibusverordening. Concrete invulling voor Nederland betekent dat de schadedrempel van de Brede Weersverzekering van 30\% naar 20\% verlaagd kan worden en het toegestane subsidiepercentage verhoogd kan worden van $65 \%$ naar $70 \%$. Het is ook gewenst om de budgettaire consequenties van het niveau waarop de schadedrempel in de verzekeringspolis moet worden bepaald in beeld te krijgen. Deze studie draagt bij aan het verder onderbouwen van de verwachte subsidieomvang in relatie met een (mogelijke) regelingswijziging Brede Weersverzekering.

Trefwoorden: Brede Weersverzekering, subsidie, risico

Dit rapport is gratis te downloaden op https://doi.org/10.18174/463818 of op www.wur.nl/economicresearch (onder Wageningen Economic Research publicaties).

(C) 2018 Wageningen Economic Research Postbus 29703, 2502 LS Den Haag, T 07033583 30, E communications.ssg@wur.nl, www.wur.nl/economic-research. Wageningen Economic Research is onderdeel van Wageningen University \& Research.

\section{(c) BY-NC}

Wageningen Economic Research hanteert voor haar rapporten een Creative Commons Naamsvermelding 3.0 Nederland licentie.

(C) Wageningen Economic Research, onderdeel van Stichting Wageningen Research, 2018

De gebruiker mag het werk kopiëren, verspreiden en doorgeven en afgeleide werken maken. Materiaal van derden waarvan in het werk gebruik is gemaakt en waarop intellectuele eigendomsrechten berusten, mogen niet zonder voorafgaande toestemming van derden gebruikt worden. De gebruiker dient bij het werk de door de maker of de licentiegever aangegeven naam te vermelden, maar niet zodanig dat de indruk gewekt wordt dat zij daarmee instemmen met het werk van de gebruiker of het gebruik van het werk. De gebruiker mag het werk niet voor commerciële doeleinden gebruiken.

Wageningen Economic Research aanvaardt geen aansprakelijkheid voor eventuele schade voortvloeiend uit het gebruik van de resultaten van dit onderzoek of de toepassing van de adviezen.

Wageningen Economic Research is ISO 9001:2008 gecertificeerd.

Wageningen Economic Research Nota 2018-096 | Projectcode 2282300320

Foto omslag: Shutterstock 


\section{Inhoud}

1

Inleiding $\quad \mathbf{5}$

1.1 Aanleiding en uitgangspunten $\quad 5$

1.2 Doelstelling $\quad 6$

$2 \quad$ Data, methode en afbakening $\quad 7$

$\begin{array}{lll}2.1 & \text { Data } & 7\end{array}$

$\begin{array}{lll}2.2 & \text { Scenario's } & 7\end{array}$

2.3 Stappenplan $\quad 8$

2.4 Afbakening $\quad 8$

3

$\begin{array}{ll}\text { Resultaten } & 9\end{array}$

3.1 Beschrijvende data-analyse $\quad 9$

3.1.1 Data RVO.nl 9

3.1.2 Data verzekeringsmaatschappijen 11

$\begin{array}{ll}3.2 \text { Modeluitkomsten } & 13\end{array}$

$4 \quad$ Conclusie en discussie $r$

$\begin{array}{lll}4.1 & \text { Conclusie } & 15\end{array}$

4.2 Discussie 15

$\begin{array}{ll}\text { Literatuur en websites } & 16\end{array}$ 



\section{$1 \quad$ Inleiding}

\subsection{Aanleiding en uitgangspunten}

De maatregelen van de Health Check van 2008 in het Gemeenschappelijk landbouwbeleid (GLB) biedt lidstaten de mogelijkheid om risicomanagementinstrumenten financieel te ondersteunen (Artikel 68, Verordening 73/2009). In de GLB-hervorming van 2013 (geldend voor de periode 2014-2020) is een meer omvattende aanpak inzake risicobeheer ingevoerd. In Artikel 37 (Verordening 1305/2013) zijn premiesubsidies toegestaan met GLB-middelen voor oogst-, dieren- en plantenverzekering tegen economische verliezen voor landbouwers als gevolg van ongunstige weersomstandigheden, dier- of plantenziekten, plaagorganismen, of milieu-incidenten (EU, 2013).

Nederland heeft in 2010 de Regeling Brede Weersverzekering vastgesteld (ondersteund eerst met premiesubsidie via Verordening 73/2009 en later via Verordening 1305/2013). De verzekering dekt het financieel verlies van een teler voor zover dat (Staatscourant, 2015):

- meer is dan $30 \%$ van de gemiddelde jaarproductie in de laatste drie jaar (of van de gemiddelde productie van drie van de laatste vijf jaar waarbij de hoogste en laagste productie van deze vijf jaar niet wordt meegerekend)

- het gevolg is van een lagere opbrengst in kwantiteit of kwaliteit

- optreedt op een aaneengesloten stuk grond waarop één enkel gewas wordt geteeld

- redelijkerwijs is toe te rekenen aan ongunstige weersomstandigheden.

De verplichte schadedrempel van 30\% (de grenswaarde die gepasseerd moet zijn alvorens een subsidieerbare verzekering tot schade-uitkering mag overgaan) is in lijn met het gedachtegoed dat het een calamiteitendekking betreft (tegemoetkoming schadelast, wat een lagere gesubsidieerde premie tot gevolg heeft, in plaats van schadeloosstelling). ${ }^{1}$ Overigens is de gehanteerde hoogte van het eigen risico een keuze van de verzekeraars. De verplichting hiertoe geeft het subsidiekader Brede Weersverzekering niet. Door de premie te subsidiëren is de Brede Weersverzekering toegankelijk geworden voor alle open teelten en zijn alle belangrijke weersrisico's afgedekt. Sinds openstelling in 2010 is het aantal verzekerden toegenomen tot circa 1.812 in 2018.

Het jaarlijkse uitbetaalde bedrag aan premiesubsidie is gestegen van $€ 3,1 \mathrm{mln}$. in 2010 tot $€ 11,23 \mathrm{mln}$. voor de Regeling Brede Weersverzekering (nationaal en POP3-budget samen) in 2018. Bij overschrijding van het plafondbedrag wordt het gangbare percentage van $65 \%$ neerwaarts bijgesteld (in 2016 is het percentage vastgesteld op 62\%). De dreigende premiekorting is een mogelijk knelpunt omdat dan het draagvlak voor de verzekering afneemt. Daarom is het budget voor de resterende GLB-periode (2017-2020) herschikt zodat het totaal over die jaren toeneemt met $€ 20 \mathrm{mln}$. (het beschikbaar plafondbedrag was $€ 9 \mathrm{mln}$. per jaar). Hierdoor kunnen in totaal ongeveer 1.000 tot 1.200 meer deelnemers worden geaccommodeerd, wat bijna een verdubbeling is van het aantal in 2016 (Ministerie van Economische Zaken, 2017).

De Europese Raad van landbouwministers heeft eind december 2017 ingestemd met de landbouwonderdelen van de Omnibusverordening (EU, 2017). Deze verordening is van toepassing vanaf 2018. Een van de belangrijkste wijzigingen is dat risicobeheersmaatregelen nog meer gestimuleerd mogen worden dankzij een verlaging van schadedrempels en een verhoging van de steun. De schadedrempel van de Brede Weersverzekering kan van $30 \%$ naar $20 \%$ verlaagd worden. Het toegestane subsidiepercentage van de premie kan worden verhoogd van $65 \%$ naar $70 \%$. Het ministerie van LNV wil de Regeling Brede Weersverzekering vanaf 2019 mogelijk herzien; passend binnen de nieuwe, bovengenoemde EU-kaders (Omnibusverordening).

\footnotetext{
${ }^{1}$ De drempelwaarde heeft betrekking op de gemiddelde jaarproductie en is mogelijk voor elk afzonderlijk type product (Artikel 37, Verordening 1305/2013).
} 
Behalve het schadedrempelpercentage is ook het niveau waarop de schadedrempel moet worden bepaald van invloed op de verzekeringspremies en het daarmee samenhangende subsidiebedrag. ${ }^{2}$ Met deze studie wordt ook het effect daarvan (verleggen naar het totale oppervlakte van een gewas op het bedrijf in plaats van bijvoorbeeld per perceel waarop de verzekering wordt afgesloten) op het benodigde subsidiebudget verkend.

De voorgenoemde herzieningen hebben ieder afzonderlijk een mogelijk effect op de subsidieomvang (en de mogelijke kans dat het beschikbaar plafondbedrag overschreden wordt). Als de schadedrempel omlaag gaat, zal er vaker en meer uitbetaald moeten worden. Dit zal tot gevolg hebben dat de premie en subsidieomvang toenemen. Als het niveau van bepalen van de schadedrempel herzien wordt (op gewasniveau in plaats van per perceel) zal er minder vaak uitbetaald worden (met als gevolg daling premie en subsidieomvang). Deelname aan de Brede Weersverzekering komt mogelijk onder druk indien de schadedrempel per perceel niet meer mogelijk is, maar per gewas moet worden gehanteerd. Het alternatief van vrije keuze zal de vraag niet nadelig beïnvloeden. Een verhoging van het subsidiepercentage (van 65\% naar $70 \%$ ) heeft een positieve uitwerking op de vraag en subsidieomvang (maar in welke mate is op voorhand moeilijk in te schatten). Gezien de complexe uitwerking van de herziening heeft het ministerie van LNV behoefte aan een onderbouwing van de effecten van de herziening Regeling Brede Weersverzekering op de subsidieomvang in de vorm van een scenariostudie.

\subsection{Doelstelling}

Het doel van het onderzoek is het bepalen van de subsidieomvang bij de herziening Regeling Brede Weersverzekering. Hiertoe zullen de volgende onderzoeksvragen worden beantwoord met betrekking tot omvang premiesubsidie (op basis van het effect op het verzekerde areaal en premie):

1. Wat is het effect van het verlagen van de schadedrempel van $30 \%$ naar $20 \%$ op de premiesubsidie?

2. Wat is het effect van toename subsidie van $65 \%$ naar $70 \%$ op de premiesubsidie?

3. Wat is het effect van het veranderen van het niveau van bepalen van de schadedrempel (op gewasniveau in plaats van bijvoorbeeld per perceel) op de premiesubsidie?

4. Wat is het effect van de mogelijke combinaties van voorgaande wijzingen op de premiessubsidie?

\footnotetext{
2 De verzekeringsmaatschappijen hebben verschillende polissen met betrekking tot het niveau van de schadedrempel, variërend van per gewas, per perceel of per ras per perceel (allemaal passend binnen de huidige Regeling Brede Weersverzekering).
} 


\section{Data, methode en afbakening}

\section{$2.1 \quad$ Data}

De administratie van de Regeling Brede Weersverzekering verloopt via de Rijksdienst voor Ondernemend Nederland (RVO.nl) en de informatieverzameling is gekoppeld aan de Gecombineerde opgave (de jaarlijkse aanlevering van gegevens door agrarisch ondernemers aan RVO.nl) aangevuld met informatie van de aanbieders van een Brede Weersverzekering. Bij de Gecombineerde opgave geeft de teler aan (tussen 1 april en $15 \mathrm{mei}$ ) of hij voornemens is premiesubsidie te gaan aanvragen voor de Brede Weersverzekering en bij welke verzekeraar. Vanaf 2015 geven telers ook aan welke percelen (en gewassen) zij willen verzekeren. Voorheen werden de verzekerde percelen nog niet opgegeven aan RVO.nl. De verzekeraars stellen in september/oktober de voorlopige nota's op voor de premiebetaling en sturen voor 1 november de definitieve verzekeringsbedragen naar RVO.nl (die de basis vormen voor het subsidiebedrag).

Anno 2018 zijn er vijf aanbieders van een Brede Weersverzekering, namelijk Achmea-Avero, Achmea Interpolis, Agriver, BFAO/OFH, en Vereinigte Hagel. De premie van de Brede Weersverzekering is niet alleen verschillend tussen gewassen maar ook tussen verzekeringsmaatschappijen. Het Verbond van Verzekeraars heeft geen cijfers vastgelegd van de Brede Weersverzekering zoals jaarlijkse premievolume, schadeomvang en schade-uitkeringen (en worden niet gedeeld met RVO.nl). Dit specifieke verzekeringssegment heeft namelijk weinig aanbieders zodat openbare cijfers herleid zouden kunnen worden tot individuele verzekeraars.

Bij het ontwerpen van de onderzoeksmethodiek is expliciet rekening gehouden met mededingingsregels en concurrentieverhoudingen. Verzekeringsmaatschappijen analyseren de individuele verzekeringsgegevens en niet het Verbond van Verzekeraars of Wageningen Economic Research. Wageningen Economic Research, als onafhankelijke en niet-belanghebbende partij, rekent met de aangereikte premie-informatie door welke subsidiebudgetten nodig zouden zijn in de begroting van het ministerie van LNV (op basis van een aantal scenario's). Betrouwbaarheid wordt getoetst door het vergelijken van de inschattingen tussen de verzekeraars. De vermelde data en uitkomsten in de rapportage zullen niet te herleiden zijn tot individuele verzekeraars.

\subsection{Scenario's}

Met behulp van een rekenmodel en een aantal scenario's (mogelijke combinaties van individuele herzieningen (zie doelstelling 1, 2, 3,4) worden de effecten van de herziening Brede Weersverzekering op de subsidieomvang in kaart gebracht voor de periode tot en met 2020. Het eerste scenario (basisscenario) betreft een ongewijzigde Regeling Brede Weersverzekering inclusief een autonome groei van het aantal verzekerde telers. Vervolgens worden scenario's geanalyseerd waarbij het effect van de afzonderlijke herzieningen geschat wordt (inclusief autonome groei). Ook worden een aantal mogelijke combinaties van voorgaande herzieningen geanalyseerd (selectie in overleg met opdrachtgever). 
Samenvattend worden de volgende 12 scenario's geanalyseerd:

1. Basisscenario: Autonome groei maar geen herziening

2. Scenario A: Drempelwaarde $20 \%$ in plaats van $30 \%$

3. Scenario B: Subsidie $70 \%$ in plaats van $65 \%$

4. Scenario C1: Verzekering per gewas in plaats van per perceel

5. Scenario C2: Keuze verzekering per gewas of per perceel

6. Scenario $A+B$ : Scenario $A+$ Scenario $B$

7. Scenario $A+C 1$ : Scenario $A+$ Scenario $C 1$

8. Scenario $A+C 2$ : Scenario $A+$ Scenario $C 2$

9. Scenario $B+C 1$ : Scenario $B+$ Scenario $C 1$

10. Scenario $B+C 2$ : Scenario $B+$ Scenario $C 2$

11. Scenario $A+B+C 1$ : Scenario $A+$ Scenario $B+$ Scenario $C 1$

12. Scenario $A+B+C 2$ : Scenario $A+$ Scenario $B+$ Scenario $C 2$.

\subsection{Stappenplan}

De volgende stappen in de gehanteerde werkwijze zijn van belang:

1. Analyse gegevens van telers met een Brede Weersverzekering:

- RVO.nl levert de geaggregeerde gegevens aan op basis van geregistreerde verzekerde telers per jaar.

- Omvang van de portefeuille per verzekeraar (aantal bedrijven en subsidieomvang) in de jaren 2010-2018. ${ }^{3}$

- Areaal verzekerde gewassen en totaal areaal van die gewassen per verzekeraar (2018).

- Verzekeraars berekenen op basis van hun verzekeringsportefeuille, schadestatistieken en expertise zelf het effect van:

- De (gemiddelde) procentuele premiestijging bij verlaging van de schadedrempel van 30\% naar $20 \%$.

- De (gemiddelde) procentuele premiedaling bij verleggen van de schadedrempel van perceelsniveau naar gewasniveau van het bedrijf.

- De minimale en maximale ingeschatte verandering in deelname per scenario.

2. Synthese van geaggregeerde statistieken van RVO.nl en verzekeringsmaatschappijen door Wageningen Economic Research met behulp van een rekenmodel.

\subsection{Afbakening}

Het onderzoek beperkt zich op hoofdlijnen. Voor de tien hoofdgewassen zal RVO.nl nagegaan welk percentage van het areaal verzekerd is (periode 2018). Een meer gedetailleerde analyse per sector (akkerbouw, boomkwekerij, bloembollenteelt, fruitteelt, teelt van voedergewassen voor de melkveehouderij en vollegrondsgroenteteelt) valt buiten beschouwing. Essentieel is de beschikbaarheid van gegevens van RVO.nl en verzekeringsmaatschappijen. De robuustheid van de inschattingen van de verzekeringsmaatschappijen kunnen alleen op onderlinge consistentie worden getoetst (tussen verzekeringsmaatschappijen en scenario's). De analyse van schadestatistieken kan vanzelfsprekend alleen uitgevoerd worden voor meldingen waar taxaties zijn uitgevoerd (minimaal één perceel op een bedrijf met schade). De rapportage wordt zo opgesteld dat geen informatie herleid kan worden naar de desbetreffende verzekeraar.

\footnotetext{
3 In 2018 voorlopige opgave in de Gecombineerde opgave.
} 


\section{Resultaten}

\subsection{Beschrijvende data-analyse}

De beschrijvende data-analyse van verzekerde telers in de databestanden van RVO.nl en de verzekeringsmaatschappijen geeft een beeld van kwantitatieve trends en maakt het mogelijk het effect van de herzieningen in te schatten.

\subsubsection{Data RVO.nl}

Data van RVO.nl schetst (de toename van) het bereik van de Regeling Brede Weersverzekering sinds openstelling in termen van aantal verzekerde bedrijven, het (on)verzekerd areaal en het uitbetaalde bedrag aan premiesubsidie. Sinds openstelling in 2010 is het aantal verzekerden circa verviervoudigd tot 1.812 in 2018 (figuur 3.1). De gemiddelde jaarlijkse groei bedraagt $20 \%$ maar is afgezwakt in het laatste jaar. ${ }^{4}$

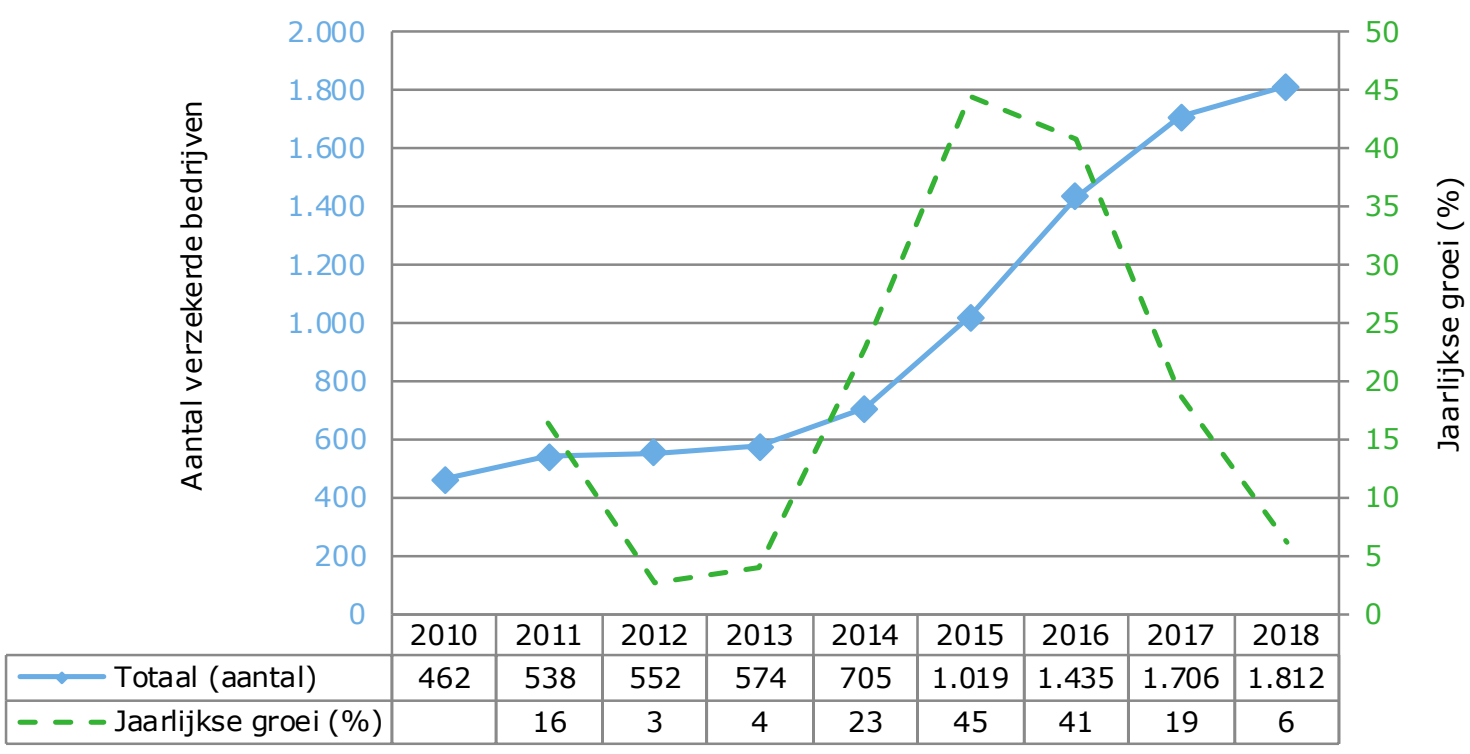

Figuur 3.1 Aantal bedrijven met een Brede Weersverzekering Bron: RVO.nl.

Vanaf 2015 wordt ook het verzekerde areaal geregistreerd in de Gecombineerde opgave. In 2018 omvatte het voorlopige verzekerd areaal 41.994 ha met een procentuele toename van $15 \%$ per jaar in recente jaren (figuur 3.2). De (procentuele) toename van het verzekerde areaal heeft is min of meer gelijk aan de (procentuele) toename van het aantal verzekerde bedrijven in recente jaren.

\footnotetext{
${ }^{4}$ Uit een uitgevoerde evaluatie Regeling Brede Weersverzekering blijkt overigens dat bedrijven met hoofdzakelijk akkerbouwgewassen of fruitteelt de voornaamste gebruikers zijn. In de recente jaren zit de groei van het aantal deelnemers vooral bij de bedrijven met akkerbouwgewassen en is het aantal deelnemers met fruit tamelijk stabiel (Berkhout et al., 2017).
} 


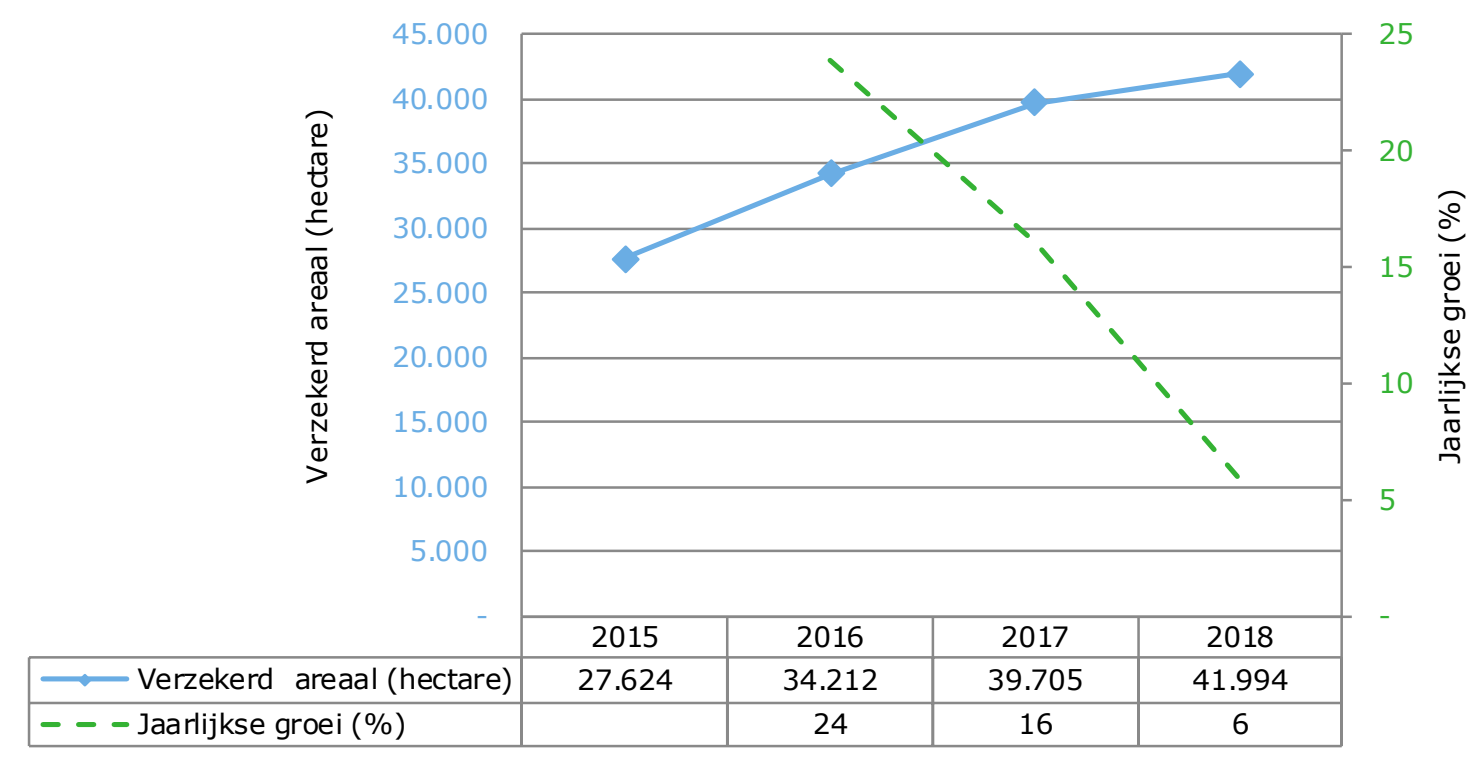

Figuur 3.2 Verzekerd areaal met Brede Weersverzekering

Bron: RVO.nl.

Voor het inschatten van de procentuele premiewijziging bij herziening (verlaging schadedrempelniveau naar $20 \%$ en schadedrempel per gewas in plaats van per perceel) hebben niet alle verzekeraars zelf inzicht of hun verzekerden naast verzekerd areaal van een gewas nog onverzekerde percelen van hetzelfde gewas telen. De verwachting is dat van de verzekerde gewassen in 2018 slechts circa $4 \%$ van dat gewasareaal niet verzekerd is op bedrijven met een Brede Weersverzekering. ${ }^{5}$ Opgemerkt dient te worden dat de verwachte verzekerde percelen in de Gecombineerde opgave weleens meer kan zijn dan de telers later daadwerkelijk verzekeren.

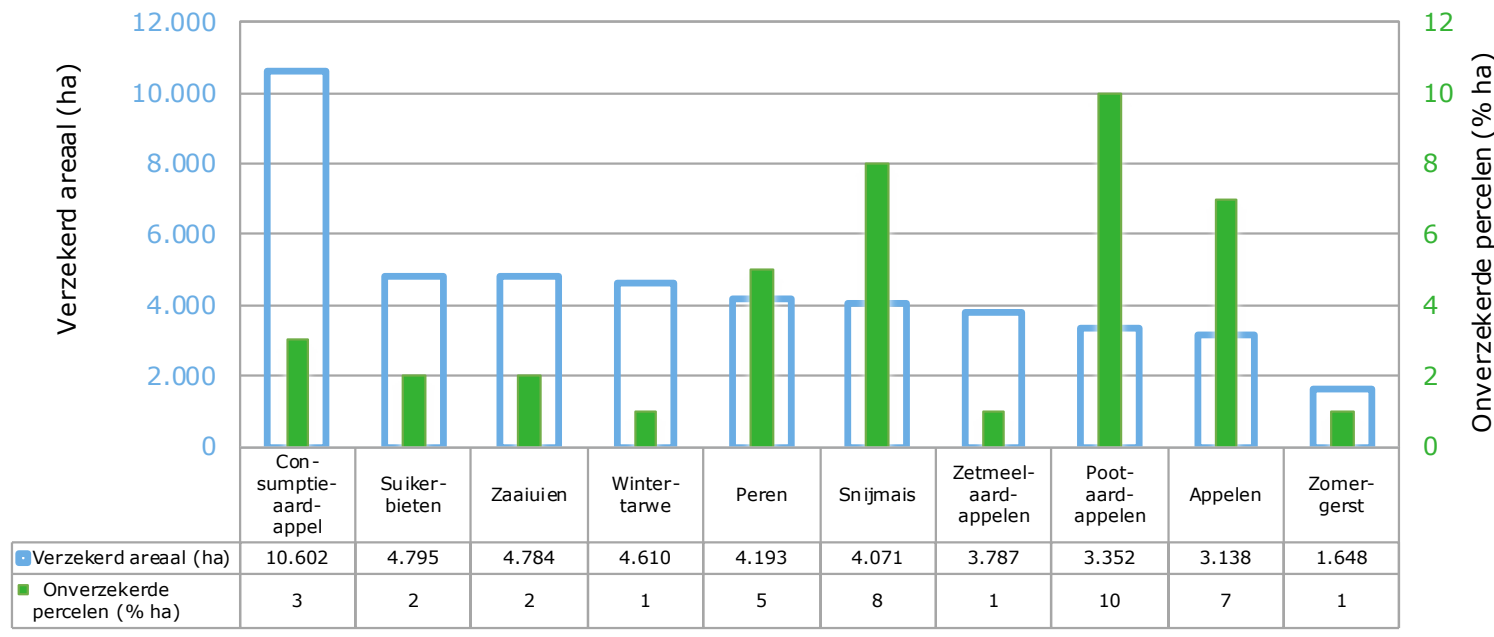

Figuur 3.3 Verzekerd areaal per gewas en percentage onverzekerd areaal (van verzekerde gewassen) op bedrijven met een Brede Weersverzekering Bron: RVO.nl.

Naast de totalen is ook nagegaan of de verhouding tussen verzekerd en onverzekerd areaal verschilt per gewas. De tien belangrijkste gewassen in de voorlopige aanvraag (indien gerangschikt naar

\footnotetext{
5 Uit een nadere analyse van de voorlopige aanvraag voor premiesubsidie in 2018 blijkt ook dat de verhouding tussen verzekerd en onverzekerd areaal op bedrijven met een Brede Weersverzekering gemiddeld 39\% bedraagt. Deze verhouding is constant in de jaren waarin ook het verzekerde areaal geregistreerd is in de Gecombineerde opgave.
} 
verzekerd areaal) zijn consumptieaardappelen, suikerbieten, zaaiuien, wintertarwe, peren, snijmais, zetmeelaardappelen, pootaardappelen, appelen en zomergerst. Het percentage onverzekerd areaal (van de verzekerde gewassen op bedrijven met een Brede Weersverzekering) varieert van $1 \%$ voor wintertarwe en zomergerst tot $10 \%$ voor pootaardappelen (figuur 3.3). ${ }^{6}$

Het jaarlijkse uitbetaalde bedrag aan premiesubsidie is gestegen van $€ 3,1 \mathrm{mln}$. in 2010 tot $€ 11,23 \mathrm{mln}$. in 2018 (figuur 3.4). De gemiddelde jaarlijkse groei bedraagt $18 \%$ (de procentuele toename van het subsidieomvang is ongeveer gelijk aan de procentuele toename van het verzekerde areaal en het aantal verzekerde bedrijven).

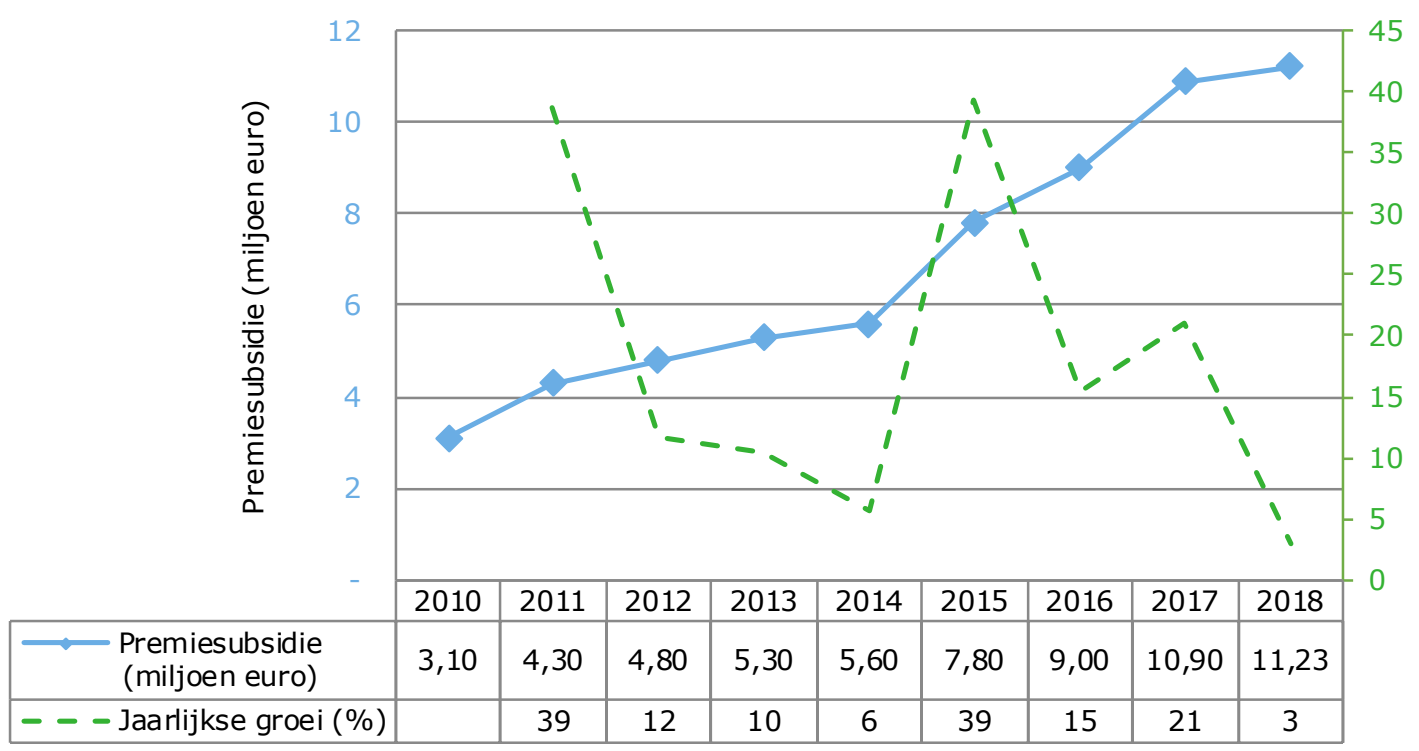

Figuur 3.4 Jaarlijkse uitbetaalde bedrag aan premiesubsidie Brede Weersverzekering Bron: RVO.nl.

De prognose van het ministerie van LNV is dat dit verder zal toenemen tot $€ 14,9 \mathrm{mln}$. en $€ 17,4 \mathrm{mln}$. in respectievelijk 2019 en 2020 op basis van een jaarlijkse groei van 16,5\% zoals die tussen 2010 en 2016 is gerealiseerd (zonder rekening te houden met herziening Regeling Brede Weersverzekering).

\subsubsection{Data verzekeringsmaatschappijen}

De voorgenoemde herzieningen hebben ieder afzonderlijk een mogelijk effect op het verwachte aantal verzekerden en de subsidieomvang (via verhoging of verlaging van de premie) zoals samengevat in tabel 3.1 op basis van inschattingen van verzekeringsmaatschappijen en aanvullende bewerkingen van Wageningen Economic Research. De verschillen tussen de verzekeringsmaatschappijen zijn relatief beperkt. De gemiddelde afwijking voor het effect op subsidieomvang per scenario is $11 \%$-punt, ofwel de inschatting per verzekeringsmaatschappij (per scenario) wijkt circa $25 \%$ af van de inschatting van alle verzekeringsmaatschappijen gezamenlijk.

\footnotetext{
6 Uit de uitgevoerde evaluatie Regeling Brede Weersverzekering blijkt dat de fruitteeltbedrijven met een Brede Weersverzekering groter zijn dan de bedrijven zonder (20 ha versus 15 ha). Op de fruitbedrijven zonder verzekering bestaat $70 \%$ van het areaal uit appel of peer, terwijl de bedrijven met een verzekering dit aandeel iets hoger ligt (78\%). In de periode 2010-2015 is de verhouding tussen de gewassen niet sterk veranderd. Evenals fruitbedrijven zijn de akkerbouwbedrijven met een verzekering groter dan de bedrijven zonder verzekering ( 84 ha respectievelijk 60 ha in 2015). De hoofdgewassen beslaan ongeveer de helft van het totale areaal. Tussen de akkerbouwbedrijven die wel en niet verzekerd zijn, is het verschil in de verhouding in geteelde hoofdgewassen marginaal en stabiel (Berkhout et al., 2017).
} 


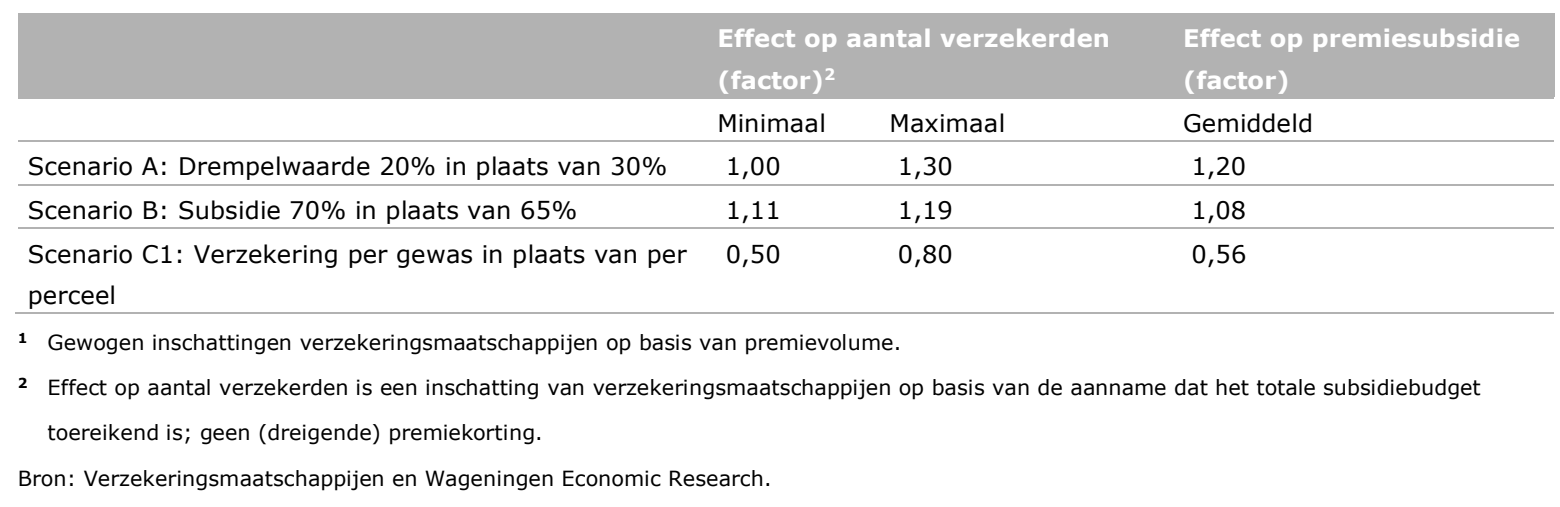

De verzekeringsmaatschappijen verwachten dat een verlaging van de schadedrempel (Scenario A: Drempelwaarde $20 \%$ in plaats van $30 \%$ ) resulteert in een stijging van het aantal verzekerden telers tot maximaal 30\% (en minimaal op het huidige niveau blijft). Als de schadedrempel omlaag gaat zullen schades frequenter vergoed worden (ook kleinere schades komen in aanmerking). Dit zal tot gevolg hebben dat de premie en subsidieomvang toenemen. De verwachting is dat de premies substantieel zullen stijgen (circa 20\%) omdat veel schades optreden tussen $20 \%$ en $30 \%$ van de verzekerde waarde (ingeschat mede op basis van historische schadeclaims en is in lijn met de theorie dat de kansverdeling scheef is). De verzekeringsmaatschappijen hebben bij de genoemde inschattingen omtrent draagvlak en omvang premie(subsidie) rekening gehouden met de wijze waarop ze het eigen risico invullen. Opgemerkt dient te worden dat de verzekeraars geen volledig beeld hebben over schades tussen $20 \%$ en $30 \%$ omdat deze, tot nu toe, niet altijd getaxeerd worden (maar deze onderschatting is beperkt omdat telers in geval van twijfel vaak laten taxeren).

Een verhoging van het subsidiepercentage (Scenario B: Subsidie $70 \%$ in plaats van $65 \%$ ) zorgt voor een stijging van $8 \%(70 / 65 * 100)$ van de subsidieomvang ten opzichte van de huidige situatie. Extra subsidie heeft een positieve uitwerking op de vraag (en subsidieomvang). De prijselasticiteit is op voorhand moeilijk in te schatten (Van der Meulen et al., 2006; Van der Meer et al., 2007). ${ }^{7}$ De verzekeringsmaatschappijen verwachten dat het aantal verzekerden telers met $11 \%$ à $19 \%$ zal toenemen bij een herziening (dit is een positiever beeld dan op basis van literatuur verwacht kan worden).

Deelname aan de Brede Weersverzekering komt mogelijk onder druk indien de schadedrempel per perceel niet meer mogelijk is (Scenario C1: Verzekering per gewas in plaats van per teelt). Als het niveau van bepalen van de schadedrempel herzien wordt (op gewasniveau in plaats van de optie per perceel) zal er minder vaak uitbetaald worden. Rekening houdend met de verschillen in getaxeerde schades per verzekerd perceel en de verschillen tussen de verzekeringsmaatschappijen wordt ingeschat dat de uitgekeerde schade (en dientengevolge premie en subsidieomvang) met $44 \%$ afneemt. Dit percentage is een robuuste inschatting (gebaseerd op historisch claimgegevens) en kan niet extern gevalideerd worden vanwege ontbreken literatuur voor deze specifieke herziening. Diegene die verzekerd willen blijven zullen het gehele areaal van een gewas verzekeren (in de huidige situatie is $4 \%$ onverzekerd). Ook een sterke afname wordt verwacht qua deelname (met een minimum en maximum deelname van respectievelijk $50 \%$ en $80 \%$ ten opzichte van de huidige deelname). Een hoge uitstroom van deelnemers wordt verwacht aangezien het 'nieuwe verzekeringsproduct' nog meer het karakter krijgt van een calamiteitenverzekering. Alleen in 'extreme situaties' komt er een aanzienlijke uitkering beschikbaar. Anderzijds hebben de telers weinig alternatieven en kan het wel eens zijn dat de uitstroom alleen wat hoger is onder de categorie bedrijven, die hun percelen wat meer verspreid hebben liggen. Als gevolg van de verschillende argumenten is de bandbreedte aanzienlijk volgens de verzekeringsmaatschappijen. Er is wel consensus dat het overgrote deel van de

\footnotetext{
7 Op basis van een literatuuroverzicht wordt geschat dat de prijselasticiteit van de vraag van oogstverzekeringen in Amerika in de eerste helft van de jaren negentig circa $-0,5$ bedraagt. Dit betekent dat indien de premie met bijvoorbeeld $10 \%$ daalt, de vraag met $5 \%$ stijgt. In de tweede helft van de jaren negentig en begin $21 \mathrm{e}$ eeuw is echter deze relatie minder sterk (circa gehalveerd) vanwege substantiële veranderingen van de polisvoorwaarden (Serra et al., 2003).
} 
telers (95\%) een voorkeur heeft voor de huidige opzet (van belang voor doorrekenen Scenario C2 (keuze verzekering per gewas in plaats van per teelt) en daarvan afgeleide samengestelde scenario's.

Effecten van de mogelijke combinaties van voorgaande individuele herzieningen zijn vervolgens bepaald (multiplicatief). Interactie-effecten, waarbij de combinatie van herzieningen meer of minder effect heeft dan de herzieningen afzonderlijk, is moeilijk in te schatten. De verwachting is echter dat deze effecten marginaal zijn (ten opzichte van de onzekerheden van de individuele herzieningen) en zijn daarom niet meegenomen.

\subsection{Modeluitkomsten}

De uitkomsten van de scenarioberekeningen zijn weergeven in tabel 3.2. De onzekerheid van de verwachte autonome groei $(5 \%-15 \%)$ in combinatie met de effecten van de herzieningen is gekwantificeerd op basis van de minimale en maximale premiesubsidie voor 2019 en $2020 .^{8}$ Bij een ongewijzigde regeling (basisscenario) zal de premiesubsidie in 2020 tussen de $€ 12,38 \mathrm{mln}$. en $€ 14,85 \mathrm{mln}$. bedragen. De bovenkant van de inschatting voor 2019 en 2020 is lager dan het maximaal beschikbare bedrag van circa $€ 32 \mathrm{mln}$. voor 2019 en 2020 samen.

Tabel $3.2 \quad$ Subsidieomvang bij herziening Regeling Brede Weersverzekering ${ }^{1}$

\begin{tabular}{|c|c|c|c|c|c|c|c|c|c|}
\hline & 2016 & & 2017 & & 2018 & 2019 & & 2020 & \\
\hline Scenario & & & & & Raming & Min. & Max. & Min. & Max. \\
\hline \multirow{2}{*}{$\begin{array}{l}\text { Basisscenario } \\
\text { (ongewijzigd) }\end{array}$} & 9,00 & & 10,93 & & 11,23 & 11,79 & 12,91 & 12,38 & 14,85 \\
\hline & & & - & & - & Min. & Max. & Min. & Max. \\
\hline $\begin{array}{l}\text { Scenario A: } \\
\text { Drempelwaarde } 20 \% \\
\text { in plaats van } 30 \%\end{array}$ & - & & - & & - & 14,14 & 20,13 & 14,85 & 23,15 \\
\hline $\begin{array}{l}\text { Scenario B: } \\
\text { Subsidie } 70 \% \\
\text { in plaats van } 65 \%\end{array}$ & - & & - & & - & 14,16 & 16,55 & 14,87 & 19,03 \\
\hline $\begin{array}{l}\text { Scenario C1: } \\
\text { Verzekering per gewas } \\
\text { in plaats van perceel }\end{array}$ & - & & - & & - & 3,30 & 5,78 & 3,46 & 6,65 \\
\hline $\begin{array}{l}\text { Scenario C2: Keuze } \\
\text { verzekering per gewas } \\
\text { of per perceel }\end{array}$ & - & & - & & - & 11,79 & 12,91 & 12.38 & 14,85 \\
\hline Scenario A+B & - & - & - & - & - & 16,98 & 25,80 & 17,83 & 29,67 \\
\hline Scenario $\mathrm{A}+\mathrm{C} 1$ & - & - & - & - & - & 3,96 & 9,01 & 4,15 & 10,37 \\
\hline Scenario $\mathrm{A}+\mathrm{C} 2$ & - & & - & & - & 14,14 & 20,13 & 14,85 & 23,15 \\
\hline Scenario $B+C 1$ & - & & - & & - & 3,96 & 7,41 & 4,16 & 8,52 \\
\hline Scenario $\mathrm{B}+\mathrm{C} 2$ & - & & - & & - & 14,16 & 16,55 & 14,87 & 19,03 \\
\hline Scenario $A+B+C 1$ & - & & - & & - & 4,75 & 11,55 & 4,99 & 13,28 \\
\hline Scenario $A+B+C 2$ & - & & - & & - & 16,98 & 25,80 & 17,83 & 29,67 \\
\hline
\end{tabular}

1 Effect op aantal verzekerden (en dus subsidieomvang) op basis van de aanname dat het totale subsidiebudget toereikend is; geen (dreigende) premiekorting.

Bron: Wageningen Economic Research.

Het verlagen van de drempelwaarde (Scenario A) of het verhogen van de premiesubsidie (Scenario B) resulteren in een verhoging van het benodigde subsidiebudget. Daarentegen is de verwachting dat een verzekering per teelt in plaats van per perceel (Scenario C1) zal resulteren in een daling van het

8 Prognose voor 2019 en 2020 (en lange termijn) is een afname van de groei door marktverzadiging. 
benodigde subsidiebudget (Scenario C2 verschilt nauwelijks van basisscenario). De bandbreedtes nemen verder toe bij een combinatie van voorgaande individuele herzieningen (met het hoogste benodigde subsidiebudget voor Scenario $A+B+C 2$ ). Alle onderzochte herzieningen doorvoeren (met keuze) resulteert in een benodigde subsidiebudget tussen de $€ 17,83 \mathrm{mln}$. en $€ 29,67 \mathrm{mln}$. in 2020 (Scenario $A+B+C 2)$. De bovenkant van de inschatting voor 2019 en $2020(25,80+29,67=55,46)$ is hoger dan het maximaal beschikbare bedrag van circa $€ 32 \mathrm{mln}$. voor 2019 en 2020 tezamen. 


\section{$4 \quad$ Conclusie en discussie}

\section{$4.1 \quad$ Conclusie}

Sinds de openstelling van de Regeling Brede Weersverzekering in 2010 is het aantal verzekerde telers toegenomen tot 1.812 in 2018. De Europese Raad van landbouwministers heeft eind december 2017 ingestemd met de landbouwonderdelen van de Omnibusverordening. Concrete invulling voor Nederland betekent dat de schadedrempel van de Brede Weersverzekering van 30\% naar $20 \%$ verlaagd kan worden en het toegestane subsidiepercentage verhoogd kan worden van $65 \%$ naar $70 \%$. Behalve het schadedrempelpercentage is ook het niveau waarop de schadedrempel moet worden bepaald van invloed op de verzekeringspremies en het daarmee samenhangende subsidiebedrag. Het ministerie van LNV wil de Regeling Brede Weersverzekering vanaf 2019 herzien, passend binnen de nieuwe, gewijzigde bovengenoemde EU-kaders. Deze studie draagt bij aan het verder onderbouwen van mogelijke regelingswijziging Brede Weersverzekering. De uitkomsten van de afzonderlijke en gecombineerde mogelijke regelingswijziging zijn weergegeven in tabel 3.2. Alle onderzochte herzieningen doorvoeren (met keuze) resulteert in een benodigde subsidiebudget tussen de $€ 17,83 \mathrm{mln}$. en $€ 29,67 \mathrm{mln}$. in 2020 (Scenario $A+B+C 2$ ). De inschatting voor 2019 en 2020 is hoger dan het maximaal beschikbare bedrag van circa $€ 32 \mathrm{mln}$. voor 2019 en 2020 tezamen. Ter vergelijk, bij een ongewijzigde regeling (basisscenario) zal de premiesubsidie in 2020 tussen de $€ 12,38 \mathrm{mln}$. en $€ 14,85 \mathrm{mln}$. bedragen. De bovenkant van de inschatting voor 2019 en 2020 is lager dan het maximaal beschikbare bedrag van circa $€ 32 \mathrm{mln}$. voor 2019 en 2020 tezamen. Indien alle onderzochte herzieningen doorgevoerd worden (met keuze) zal het totale subsidiebudget verhoogd moeten worden om een dreigende premiekorting te voorkomen.

\subsection{Discussie}

Een belangrijke aanname in de uitgevoerde modelberekeningen is dat de verzekeringsmaatschappijen de polisvoorwaarden, en met name het eigen risico en keuzevrijheid, niet verder aanpassen dan strikt noodzakelijk is voor de herziening. De meeste verzekeringsmaatschappijen hanteren een eigen risico dat gelijk is aan de schadedrempel. Echter, BFAO/OFH hanteert voor appels, peren en pruimen twee eigen risico percentages naar keuze ( $25 \%$ en $50 \%$ ) waarbij het percentage geleidelijk afneemt naar mate de schade oploopt. Deze invulling is conform EU regelgeving (Artikel 37, Verordening 1305/2013). Ook in enkele andere EU-lidstaten is het eigen risico niet gelijk aan de drempelwaarde. In Italië bijvoorbeeld varieert het eigen risico per verzekeringsmaatschappij tussen $10 \%$ en $30 \%$ (in de periode voorafgaande aan de Omnibusverordening). Het verder verlagen van het eigen risico (lager dan $20 \%$ voor die maatschappijen die momenteel het eigen risico gelijkstellen aan de drempelwaarde) zal het benodigde subsidiebudget verhogen.

Het staat de verzekeringsmaatschappijen vrij om een drempelwaarde te hanteren per perceel (of drempelwaarde te verlagen) zolang er voor de extra premie geen subsidieaanvraag wordt ingediend. In Frankijk bijvoorbeeld kunnen telers de drempelwaarde verlagen; telers hebben de keuze voor een dekking met een drempelwaarde van $25 \%$ per gewas met $45 \%$ subsidie in plaats van $65 \%$ subsidie met een standaard drempelwaarde van $30 \%$ (in de periode voorafgaande aan de Omnibusverordening). In de meeste andere lidstaten is een dekking per gewas (of bedrijf) minder een knelpunt omdat daar droogte het grootste risico is (met schade in een groot gebied zodat het effect van een drempel van $20 \%$ á $30 \%$ niet zo divers is tussen percelen). In Nederland zijn de belangrijkste risico's extreme neerslag en hagel (die vaak lokaal schade veroorzaken). Daarnaast worden in Nederland met name gewassen geteeld met hoge opbrengsten en bijbehorende kosten (een schade van $20 \%$ á $30 \%$ verlies in productie $(\mathrm{kg})$ veroorzaakt een veel hogere procentuele inkomensderving). In de komende herziening van het GLB kan Nederland deze verbijzondering als voorstel desgewenst inbrengen (zoals drempel per perceel in het geval van enkele specifieke weer gerelateerde risico's of drempel van $20 \%$ van het gemiddelde jaarinkomen zoals in het inkomensstabiliseringsinstrument (Artikel 39, Verordening 1305/2013). 


\section{Literatuur en websites}

Berkhout, P., M. van Asseldonk, R. van der Meer, H. van der Meulen en H. Silvis (2017). Evaluatie Regeling Brede Weersverzekering. Rapport 2016-070, LEI Wageningen UR.

EU (2013). Verordening (EU) nr. 1308/2013 van het Europees parlement en de raad. Brussels, 17 december 2013.

EU (2017). Regulation of the European parliament and of the council amending Regulations (EU) No $1305 / 2013$ on support for rural development by the European Agricultural Fund for Rural Development (EAFRD), (EU) No 1306/2013 on the financing, management and monitoring of the common agricultural policy, (EU) No 1307/2013 establishing rules for direct payments to farmers under support schemes within the framework of the common agricultural policy, (EU) No $1308 / 2013$ establishing a common organisation of the markets in agricultural products and (EU) No 652/2014 laying down provisions for the management of expenditure relating to the food chain, animal health and animal welfare, and relating to plant. Brussels, 12 December 2017

Ministerie van Economische Zaken (2017). Aanbieding evaluatierapport Regeling Subsidiëring brede Weersverzekering. Den Haag.

Serra, T., B.K. Goodwin en A.M. Featherstone (2003). Modeling changes in the U.S. demand for crop insurance during the 1990s. Agricultural Finance Review, Fall, 109-125.

Staatscourant (2015). Regeling van de Staatssecretaris van Economische Zaken van 21 januari 2015, nr. WJZ/14170735, houdende regels tot het subsidiëren van de premie voor een Brede Weersverzekering (Regeling Brede Weersverzekering). Den Haag, 23 januari 2015, Nr. 2276.

Van der Meer, R.W., M.A.P.M. van Asseldonk en H.A.B. van der Meulen (2007). Klimaat voor verzekeren? Oogstschadeverzekering in de akkerbouw. Rapport 6.07.07 LEI Den Haag, 2007.

Van der Meulen, H., M. van Asseldonk, J. Buurma en J. Nienhuis (2006). Mogelijkheden van een Brede Weersverzekering. Rapport 6.06.15, LEI Den Haag. 
Wageningen Economic Research Postbus 29703

2502 LS Den Haag

T 0703358330

Ecommunications.ssg@wur.nl

www.wur.nl/economic-research

Wageningen Economic Research NOTA

2018-096
De missie van Wageningen University \& Research is 'To explore the potential of nature to improve the quality of life'. Binnen Wageningen University \& Research bundelen Wageningen University en gespecialiseerde onderzoeksinstituten van Stichting Wageningen Research hun krachten om bij te dragen aan de oplossing van belangrijke vragen in het domein van gezonde voeding en leefomgeving. Met ongeveer 30 vestigingen, 5.000 medewerkers en 10.000 studenten behoort Wageningen University \& Research wereldwijd tot de aansprekende kennisinstellingen binnen haar domein. De integrale benadering van de vraagstukken en de samenwerking tussen verschillende disciplines vormen het hart van de unieke Wageningen aanpak. 



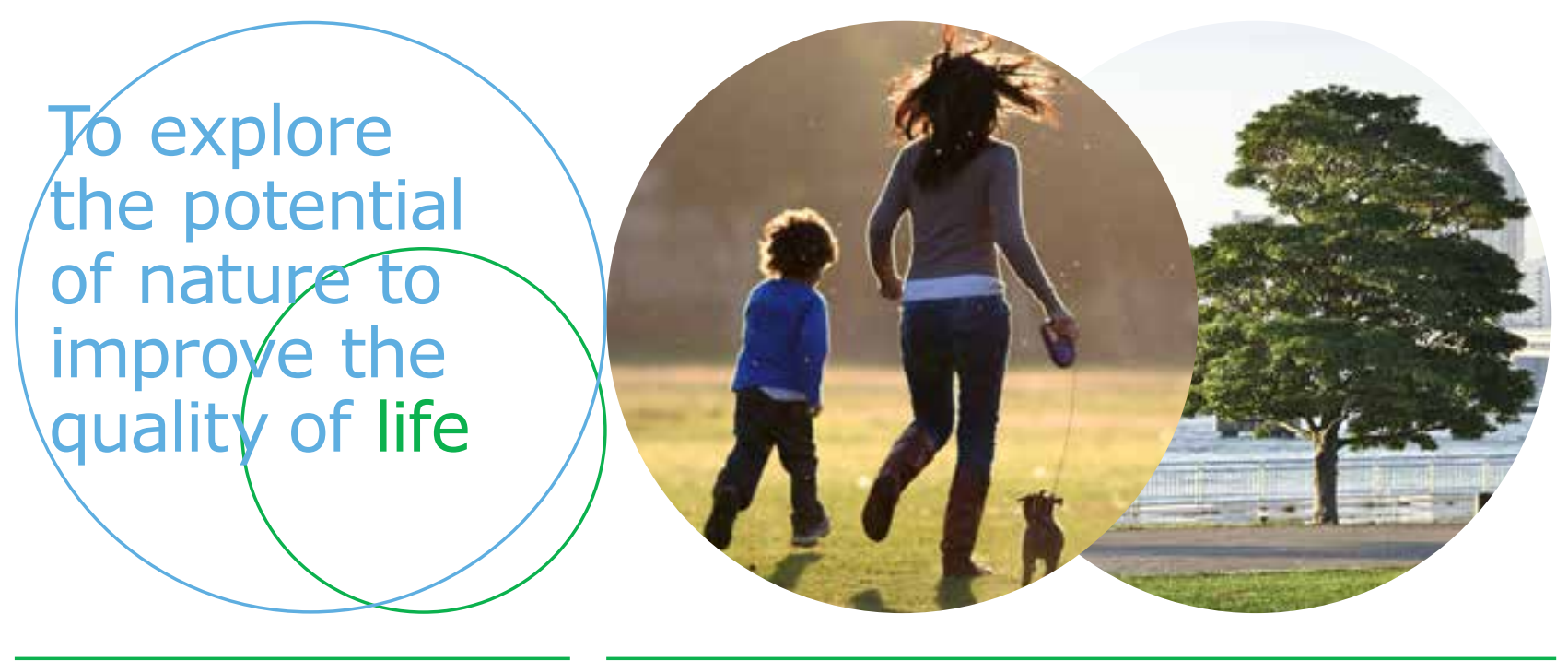

Wageningen Economic Research Postbus 29703

2502 LS Den Haag

E communications.ssg@wur.nl

T+31(0)7033583 30

www.wur.nl/economic-research

Nota 2018-096
De missie van Wageningen University \& Research is 'To explore the potential of nature to improve the quality of life'. Binnen Wageningen University \& Research bundelen Wageningen University en gespecialiseerde onderzoeksinstituten van Stichting Wageningen Research hun krachten om bij te dragen aan de oplossing van belangrijke vragen in het domein van gezonde voeding en leefomgeving. Met ongeveer 30 vestigingen, 5.000 medewerkers en 10.000 studenten behoort Wageningen University \& Research wereldwijd tot de aansprekende kennisinstellingen binnen haar domein. De integrale benadering van de vraagstukken en de samenwerking tussen verschillende disciplines vormen het hart van de unieke Wageningen aanpak. 